\title{
Table S1. Bacterial strains and plasmids used in this study
}

\begin{tabular}{|c|c|c|}
\hline Strains or Plasmids & Description & Source/ reference \\
\hline Escherichia coli $\mathrm{DH} 5 \alpha$ & \multicolumn{2}{|l|}{$\begin{array}{l}\text { F- } \text { Ф80dlacZ } \Delta \mathrm{M} 15 \Delta(\text { lacZYA-argF) } \mathrm{U} 169 \text { recA1 endA1, hsdR17(rk-, mk+) phoA sup E44 } \lambda \text { - Invitrogen } \\
\text { thi-1 gyrA96 relA1 }\end{array}$} \\
\hline Escherichia coli BL21(DE3) & $\mathrm{F}^{-}$ompT gal dcm lon $h s d S_{B}\left(r_{B}^{-} m_{B}^{-}\right) \lambda(\mathrm{DE} 3[$ lacI lacUV5-T7 gene 1 ind1 sam 7 nin5] & Invitrogen \\
\hline \multicolumn{2}{|c|}{$\begin{array}{l}\text { Pseudomonas syringae pv. tomato strain Isolated from tomato plants, also infects Arabidopsis, } \text { Rif }^{\mathrm{R}} \\
\text { DC } 3000\end{array}$} & Cuppels, 1986 \\
\hline \multicolumn{2}{|c|}{$\begin{array}{l}\text { Pseudomonas syringae pv. tomato strain A mutant of PtoDC3000 that does not produce coronatine, } \text { Rif }^{\mathrm{R}}, \mathrm{Kan}^{\mathrm{R}} \\
\text { DC3118 }\end{array}$} & $\begin{array}{l}\text { Melloto et al., 2006; } \\
\text { Moore et al, } 1989\end{array}$ \\
\hline $\begin{array}{l}\text { Agrobacterium tumefaciens } \\
\text { GV3101(pMP90) }\end{array}$ & Rif $^{\mathrm{R}}, \mathrm{Gent}^{\mathrm{R}}$ & Holsters, 1980 \\
\hline $\begin{array}{l}\text { Agrobacterium tumefaciens } \mathrm{C} 58 \mathrm{C} 1 \\
(\mathrm{pCH} 32)\end{array}$ & Rif $^{R}$, Tet $^{R}$ & Mudgett et al., 2000 \\
\hline pUCP18 & Plasmid vector multiplies in $P$. syringae, $\mathrm{Amp}^{\mathrm{R}}$ & Schweizer, 1991 \\
\hline pUCP18::HopZ1a-HA & $\begin{array}{l}\text { pUCP18 carrying the gene encoding HopZ1a tagged with HA and under the control of the } \\
\text { native promoter, } \mathrm{Amp}^{\mathrm{R}}\end{array}$ & This study \\
\hline pUCP18::HopZ1a(C216A)-HA & $\begin{array}{l}\text { pUCP18 carrying the gene encoding the HopZ1a catalytic mutant with Cys } 216 \text { replaced with } \\
\text { an alanine, Amp }\end{array}$ & This study \\
\hline pUCP18::HopZ1a(G2A)-HA & $\begin{array}{l}\text { pUCP18 carrying the gene encoding the HopZ1a mutant with Gly2 replaced with an alanine, } \\
\text { Amp }^{\mathrm{R}}\end{array}$ & This study \\
\hline pDSK600::avrRpt2 & pDSK600 carrying avrRpt 2 gene under the control of its own promoter, $\operatorname{Rif}^{\mathrm{R}}, \mathrm{Kan}^{\mathrm{R}}$ & $\begin{array}{l}\text { Mudgett and Staskawicz, } \\
1999\end{array}$ \\
\hline pUCP20tk & Plasmid vector multiplies in $P$. syringae, $\mathrm{Kan}^{\mathrm{R}}$ & Zhou et al., 2009 \\
\hline pUCP20tk::hopZ1a-HA & $\begin{array}{l}\text { pUCP20tk carrying the gene encoding HopZ1a tagged with HA and under the control of the } \\
\text { native promoter, } \operatorname{Kan}^{\mathrm{R}}\end{array}$ & Ma et al., 2006 \\
\hline pUCP20tk::hopZ1a(C216A)-HA & $\begin{array}{l}\text { pUCP20tk carrying the gene encoding the HopZ1a catalytic mutant with Cys } 216 \text { replaced } \\
\text { with an alanine, } \operatorname{Kan}^{\mathrm{R}}\end{array}$ & Zhou et al., 2009 \\
\hline pMDD1 & A binary vector with cauliflower mosaic virus $35 S$ promoter, $\operatorname{Kan}^{\mathrm{R}}$ & Mudgett et al., 2000 \\
\hline pMDD1::hopZ1a-HA & pMDD1 carrying hopZla tagged with HA, $\operatorname{Kan}^{\mathrm{R}}$ & Zhou et al., 2009 \\
\hline pMDD1::hopZ1a(C216A)-HA & pMDD1 carrying hopZ1a(C216A) tagged with HA, $\operatorname{Kan}^{\mathrm{R}}$ & Zhou et al., 2009 \\
\hline pMD1::avrRpt2-HA & pMD1 carrying avrRpt2 tagged with $\mathrm{HA}, \mathrm{Kan}^{\mathrm{R}}$ & G. Coaker \\
\hline
\end{tabular}


pEG100::GmJAZ1-FLAG

pEG100::3 ×FLAG-HopZ1a

pEG100::3 ×FLAG-HopZ1a(C216A)

pEG101

pEG101::GmJAZ1

pEG101::AtJAZ6

pEG101::AtJAZ6 Jas

pSPYNE

pSPYCE

pSPYNE::hopZ1a(C216A)

pSPYCE::GmJAZ1

pSPYCE::AtJAZ6

pGEX4T-2

pGEX4T-2::hopZ1a

pGEX4T-2::hopZ1a(C216A)

pET14b

pET14b::GmJAZ1

pET-mal

pET-mal::AtJAZ

pET-mal::AtJAZ6ムJas

pENTR/D-TOPO

pENTR/D-TOPO::3 $\times F L A G-h o p Z 1 a$

pENTR/D-TOPO ::3 $\times F L A G$ -

hopZ1a(C216A)
pEarleyGate100, a Gateway binary vector with cauliflower mosaic virus $35 S$ promoter, Kan ${ }^{\mathrm{R}}$ Earley et al., 2006

pEG100 carrying GmJAZ1 tagged with FLAG at the C-terminus, Kan ${ }^{\mathrm{R}}$ This study

pEG100 carrying hopZla tagged with $3 \times$ FLAG at N-terminus, $\mathrm{Kan}^{\mathrm{R}}$ This study

pEG100 carrying hopZ1a(C216A) tagged with $3 \times$ FLAG at N-terminus, Kan $^{\mathrm{R}} \quad$ This study

pEarleyGate101, a Gateway binary vector for YFP fusion protein expression with cauliflower Earley et al., 2006 mosaic virus $35 S$ promoter, $\operatorname{Kan}^{\mathrm{R}}$

GmJAZ1 is in-frame fused to YFP and HA, $\operatorname{Kan}^{\mathrm{R}}$ This study

AtJAZ6 is in-frame fused to YFP and HA, $\operatorname{Kan}^{\mathrm{R}}$ This study

AtJAZ6 JJas (with 10 aa deletion in the Jas domain) is in-frame fused to YFP and HA, Kan ${ }^{\mathrm{R}}$ This study

A binary vector with cauliflower mosaic virus $35 S$ promoter and the N-terminal (1-155 aa) Walter et al., 2004 domain of YFP (nYFP), Kan ${ }^{\mathrm{R}}$

A binary vector with cauliflower mosaic virus 35s promoter and the C-terminal (156-239 aa) Walter et al., 2004 domain of YFP (cYFP), $\operatorname{Kan}^{\mathrm{R}}$

pSPYNE carrying hopZ1a $(C 216 A)$ in-frame fused with nYFP, $\operatorname{Kan}^{\mathrm{R}}$

Zhou et al., 2011

pSPYCE carrying GmJAZ1 in-frame fused with cYFP, $\operatorname{Kan}^{\mathrm{R}}$

pSPYCE carrying AtJAZ6 in-frame fused with cYFP, $\mathrm{Kan}^{\mathrm{R}}$

E. coli expression vector with an N-terminal GST tag, $\mathrm{Amp}^{\mathrm{R}}$

This study

This study

pGEX4T-2 carrying hopZ1a, Amp ${ }^{\mathrm{R}}$

pGEX4T-2 carrying hopZla(C216A), Amp ${ }^{\mathrm{R}}$

E. coli expression vector with an N-terminal $6 \times$ His tag, $\mathrm{Amp}^{\mathrm{R}}$

pET14b carrying GmJAZ1 with an N-terminal $6 \times \mathrm{His}$ tag, $\mathrm{Amp}^{\mathrm{R}}$

malE gene from pMAL-c2 is cloned into NdeI-XhoI site of pET28a, $\operatorname{Kan}^{\mathrm{R}}$

Amersham

Zhou et al., 2011

This study

Novagen

This study

Sweeney et al., 2005

pET-mal carrying AtJAZ genes, $\operatorname{Kan}^{\mathrm{R}}$

pET-mal carrying AtJAZ64Jas (with 10 aa deletion in the Jas domain), $\mathrm{Kan}^{\mathrm{R}}$

This study

This study

Invitrogen

This study

pENTR/D-TOPO carrying the hopZla gene with a $3 \times$ FLAG tag at the N-terminus, Kan ${ }^{\mathrm{R}}$
pENTR/D-TOPO carrying the hopZ1a(C216A) gene with a $3 \times$ FLAG tag at the N-terminus, This study 


\section{References}

1. Cuppels DA (1986) Generation and characterization of Tn5 insertion mutations in Pseudomonas syringae pv. tomato. Appl. Environ. Microbiol. 51: 323-327.

2. Earley KW, Haag JR, Pontes O, Opper K, Juehne T, et al. (2006) Gateway-compatible vectors for plant functional genomics and proteomics. Plant $J$ 45: 616-629.

3. Holsters M, Silva B, Van Vlient F, Genetello C, De Block M, et al. (1980) The functional organization of the nopaline $A$. tumefaciens plasmid pTiC58. Plasmid 3: 212-230.

4. Ma W, Dong FF, Stavrinides J, Guttman DS (2006) Type III effector diversification via both pathoadaptation and horizontal transfer in response to a coevolutionary arms race. PLoS Genet 2: e209.

5. Melotto M, Underwood W, Koczan J, Nomura K, He SY (2006) Plant stomata function in innate immunity against bacterial invasion. Cell 126: 969-980.

6. Moore RA, Starratt AN, Ma SW, Morris VL, Cuppels DA (1989) Identification of a Chromosomal Region Required for Biosynthesis of the Phytotoxin Coronatine by Pseudomonas-Syringae Pv Tomato. Canadian Journal of Microbiology 35: 910917.

7. Mudgett MB, Chesnokova O, Dahlbeck D, Clark ET, Rossier O, et al. (2000) Molecular signals required for type III secretion and translocation of the Xanthomonas campestris AvrBs2 protein to pepper plants. Proc Natl Acad Sci U S A 97: 1332413329.

8. Mudgett MB and Staskawicz BJ (1999) Characterization of the Pseudomonas syringae pv. tomato AvrRpt2 protein: demonstration of secretion and processing during bacterial pathogenesis. Molecular Microbiology 32(5): 927-941.

9. Schweizer HP (1991) Escherichia-Pseudomonas shuttle vectors derived from pUC18/19. Gene 97: 109-112.

10. Sweeney MC, Wavreille AS, Park J, Butchar JP, Tridandapani S, et al. (2005) Decoding protein-protein interactions through combinatorial chemistry: sequence specificity of SHP-1, SHP-2, and SHIP SH2 domains. Biochemistry 44: 14932-14947.

11. Walter M, Chaban C, Schutze K, Batistic O, Weckermann K, et al. (2004) Visualization of protein interactions in living plant cells using bimolecular fluorescence complementation. Plant J 40: 428-438.

12. Yang DL, Yao J, Mei CS, Tong XH, Zeng LJ, et al.(2012) Plant hormone jasmonate prioritizes defense over growth by interfering with gibberellin signaling cascade. Proceedings of the National Academy of Sciences of the United States of America 109: E1192-E1200.

13. Zhou H, Morgan RL, Guttman DS, Ma W (2009) Allelic variants of the Pseudomonas syringae type III effector HopZ1 are differentially recognized by plant resistance systems. Mol Plant Microbe Interact 22: 176-189. 
14. Zhou H, Lin J, Johnson A, Morgan RL, Zhong W, et al. (2011) Pseudomonas syringae type III effector HopZ1 targets a host enzyme to suppress isoflavone biosynthesis and promote infection in soybean. Cell Host Microbe 9: 177-186. 